\title{
Influence of different diets and oviposition substrates on Lygus rugulipennis biology (Heteroptera: Miridae)
}

\author{
Gianandrea SALERNO, Francesca FRATI, Eric CONTI and Ferdinando BIN \\ Dipartimento di Scienze Agrarie e Ambientali - Entomologia, Università di Perugia, Borgo XX Giugno 74, 06121 Perugia, Italy; \\ e-mail: salerno@unipg.it
}

Key words. Miridae, Heteroptera, Lygus rugulipennis, rearing, artificial diet, beans, reproduction, development, survival, weight

\begin{abstract}
The aim of this study was to evaluate the effects of different diets on the development and reproduction of Lygus rugulipennis Poppius (Heteroptera: Miridae). Using 2 laboratory generations (F1 and F2) obtained from field-collected L. rugulipennis, the following diets were tested: beans, beans plus Tenebrio molitor (L.) (Coleoptera: Tenebrionidae) pupae, and a commercial artificial diet, which was developed for mass rearing of Lygus hesperus Knight. As oviposition substrates, beans and agar/parafilm rolls were used. Our data show that both the artificial diet and the artificial oviposition substrate were ineffective substitutes for beans for both laboratory generations. Stage-dependent and total survival rates clearly indicated that F1 Lygus bugs survive significantly longer when they are reared on vegetable substrates i.e., beans and beans plus pupae. The differential effects of the diets were more pronounced in the F2 generation, in which the embryonic development was longer for eggs from females reared on the artificial diet than on beans, and in which the second instar nymphs did not survive on the artificial diet. Both the total duration of post-embryonic development and the longevity of F1 males were shorter on the artificial diet than on beans. Female fecundity was affected by diet in terms of total duration of the oviposition period and mean number of eggs laid/female, since these parameters were lower on the artificial substrate, compared with those obtained on the bean substrate. However, the diet did not affect the morphological parameters, as there were no significant variations in weight, width of cephalic capsule, and tibia and hemelytra length. Since L. rugulipennis cannot be reared on the commercially available artificial diet, we discuss the necessity to improve both the artificial diet and oviposition substrate so that this Lygus bug and its specific egg parasitod Anaphes fuscipennis Haliday (Hymenoptera: Mymaridae) can be mass reared.
\end{abstract}

\section{INTRODUCTION}

The European tarnished plant bug, Lygus rugulipennis Poppius (Heteroptera: Miridae), is the most common phytophagous species of the genus Lygus in Europe (Varis, 1972; Tavella et al., 1997; Schwartz \& Foottit, 1998; Colazza \& Conti, 2000). While it has a holarctic distribution (Schwartz \& Foottit, 1998), this highly polyphagous species is widely distributed (Holopainen \& Varis, 1991) on both herbaceous and woody wild plants and crops (Hill, 1987; Holopainen, 1989; Schwartz \& Foottit, 1998; Conti \& Bin, 2001; Wheeler, 2001) and has been recorded on more than 320 host plants (Holopainen, 1989). Lygus spp. damage the plants either by feeding, through the injection of saliva, which is rich in degrading enzymes such as polygalacturonase (Strong, 1970; Varis, 1972; D’Ovidio et al., 2004; Frati et al., 2006), or by oviposition, as females have a robust ovipositor, which they use to lacerate host plant to lay the eggs within plant tissues.

Over the last few decades there has been an increasing interest in Northern America in research focused on mass production of Lygus spp. in laboratory (Debolt, 1982; Patana, 1982; Debolt \& Patana, 1985; Cohen, 2000; Habibi et al., 2001; Zeng \& Cohen, 2001), in order to develop on effective method of producing the specific biological control agent Anaphes iole (Girault) (Hymenoptera: Mymaridae). In this respect, the objectives were to develop and improve the rearing methodology so that these insects can be produced continuously. Improvement of diets regarded not only the use of natural substrates, such as beans, cotton and alfalfa plants (Beards \& Leigh, 1960), or beans supplemented with animal material such as heat-killed beet armyworm Spodoptera exigua (Hübner) (Lepidoptera: Noctuidae) pupae, but also artificial diets. Artificial diets for Lygus spp. were developed assuming that they only can ingest materials that are already liquid prior to the onset of feeding. However, the presence of specific salivary enzymes indicate that they can feed on non liquid food (Cohen, 2000). Based on this premise Debolt (1982) developed the first artificial diet for $L$. hesperus Knight, which was subsequently improved by Patana (1982), and used to produce feeding packets. These packets were further improved for this same species by Cohen (2000).

Although several papers provide excellent basic information for the American species of the Lygus genus, few are on the European species L. rugulipennis and L. pratensis (L.) (Varis, 1972; Holopainen, 1989; Holopainen \& Varis, 1991; Tavella et al., 1997; Schwartz \& Foottit, 1998; Colazza \& Conti, 2000; Conti \& Bin, 2001; Wheeler, 2001) and none of them on diets. The development of an alternative rearing method for L. rugulipennis would overcome a critical obstacle to the large scale production of its most effective egg parasitoid Anaphes fuscipennis Haliday (Varis, 1972; Bilewicz-Pawińska, 1983; 
Conti et al., 1994; Coutinot \& Hoelmer, 1999), for which there is little biological and behavioural information.

Therefore, in the present work, the artificial diet developed for the American species was tested for the first time on L. rugulipennis. In particular, the effect of different diets, i.e., fresh green beans, beans plus Tenebrio molitor (L.) (Coleoptera: Tenebrionidae) pupae, and artificial diet (Debolt \& Patana, 1985) on L. rugulipennis development and reproduction, were determined. Pupae of $T$. molitor were chosen as a protein source, since in preliminary tests it was observed that these were readily preyed by L. rugulipennis.

\section{MATERIAL AND METHODS}

Adults of L. rugulipennis were collected from alfalfa fields in central Italy and kept in a controlled-environment growth chamber $\left(25 \pm 1{ }^{\circ} \mathrm{C}, 50-60 \%\right.$ r.h. and photoperiod $\left.14 \mathrm{~L}: 10 \mathrm{D}\right)$ in plastic cages $(180 \times 105 \times 100 \mathrm{~mm} ; \sim 50$ adults/cage $)$ containing strips of paper to increase the surface area for walking. The adults were fed with fresh green beans, sunflower seeds and supplied continuously with water through a glass tube, inserted in a hole and plugged with moistened cotton. The food was replaced every day and beans containing eggs, which were counted using a stereo microscope, were transferred ( $\sim 100$ eggs) to different plastic cages $(120 \times 85 \times 80 \mathrm{~mm})$ containing strips of paper to improve air circulation. Egg development was observed daily. Upon hatching, single nymphs of the $1^{\text {st }}$ laboratory generation (F1) were gently transferred, using a thin brush, to single plastic pots $(\varnothing=40 \mathrm{~mm}, \mathrm{~h}=65 \mathrm{~mm})$ kept under the same controlled environmental conditions, and fed on one of three different diets: $(1)$ beans $(\mathrm{n}=147),(2)$ beans $+T$. molitor pupae $(n=137)$ or $(3)$ artificial diet $(n=221)$. The bean diet consisted of a portion $(3 \mathrm{~cm})$ of fresh green beans, while the bean + pupae diet consisted of a similar portion of fresh green beans and one pupa of T. molitor (Esche Grifo, Perugia, Italy), to provide a source of animal proteins. In both cases the food source was changed every day. For the artificial diet, a meridic diet developed for L. hesperus (Patana \& Debolt, 1985) purchased from BIO-SERV ${ }^{\circledR}$ was fed to the bugs in a plastic cap $(\varnothing$
$=11 \mathrm{~mm}, \mathrm{~h}=8 \mathrm{~mm}$ ) covered with tight parafilm, and changed every two days.

In the case of beans and beans + pupae, the green beans served as a source of food and as an oviposition substrate. In the case of the artificial diet the oviposition substrate was an agar cylinder $(\varnothing=10 \mathrm{~mm}, 1=10 \mathrm{~mm})(1.5 \mathrm{~g}$ agar $/ 100 \mathrm{ml}$ of water $)$, totally covered with parafilm, which was slightly stretched in order to favour ovipositor insertion. This substrate was changed every day.

The entire Lygus development, through 5 nymphal instars, was followed daily and recorded until adult emergence. The adults were weighed 2 days after emergence at the same time of the day (11-12 am) and then males and females of approximately the same age ( $\sim 4$ days), separated according to diet, were allowed to mate by placing a couple in a container $(\varnothing=40$ $\mathrm{mm}, \mathrm{h}=65 \mathrm{~mm}$ ) in the same environmental conditions.

Daily observations were made to evaluate the life cycle of both males and females and the number of eggs laid in each oviposition substrate, i.e., green beans or agar. The eggs laid daily by each couple were counted and placed in plastic cages $(120 \times$ $85 \times 80 \mathrm{~mm}$ ), which were separated according to diet. Because a large number of eggs were laid on beans by females of the F1 generation, only a representative sample was taken, equal to twice the number of F1 adults. In the case of eggs embedded in the artificial oviposition substrate, the parafilm was removed, stretched and the eggs were placed on filter paper soaked with distilled water. This procedure is a modified version of that described for L. hesperus by Debolt \& Patana (1985). Eggs remaining inside the agar were drawn out gently using tweezers to avoid damaging.

The rearing of the F2 generation was done using the same technique and on the same diet as the F1 generation, and the nymphal development recorded as previously described.

The initial number of replicates per type of diet tested varied from 137 to 221 in the $\mathrm{F} 1$ and from 15 to 282 in the $2^{\text {nd }}$ generation (F2), because fewer eggs were produced by the females reared on the artificial diet. Each insect was treated as a replicate.

The following biological parameters were evaluated for each diet and generation (F1 and F2): survival rate of the nymphal stages; duration of embryonic development; stage dependent

TABLE 1. Stage-specific and total survival (\%) of F1 and F2 L. rugulipennis nymphs reared on different diets $\left(25 \pm 1{ }^{\circ} \mathrm{C}, 50-60 \%\right.$ r.h., 14L : 10D). Numbers in columns with the same letter are not significantly different (Karl Pearson $\chi^{2}$ test and Goodman's post hoc procedure).

\begin{tabular}{|c|c|c|c|c|c|c|}
\hline \multicolumn{7}{|c|}{ F1 Generation } \\
\hline Diet & $\mathrm{N} 1(\mathrm{n}=505)$ & $\mathrm{N} 2(\mathrm{n}=349)$ & $\mathrm{N} 3(\mathrm{n}=292)$ & $\mathrm{N} 4(\mathrm{n}=268)$ & N5 $(n=235)$ & $\mathrm{N} 1-\mathrm{N} 5(\mathrm{n}=505)$ \\
\hline Beans & $82.31 \mathrm{a}$ & $92.56 \mathrm{a}$ & $95.54 \mathrm{a}$ & $92.52 \mathrm{a}$ & $96.97 \mathrm{a}$ & $65.31 \mathrm{a}$ \\
\hline Beans + pupae & $76.64 \mathrm{a}$ & $93.33 \mathrm{a}$ & $92.86 \mathrm{a}$ & $92.31 \mathrm{a}$ & $95.24 \mathrm{a}$ & $58.39 \mathrm{a}$ \\
\hline Artificial diet & $55.66 \mathrm{~b}$ & $66.67 \mathrm{~b}$ & $85.37 \mathrm{a}$ & $74.29 \mathrm{~b}$ & $75.00 \mathrm{~b}$ & $17.65 \mathrm{~b}$ \\
\hline$\chi^{2}$ & 34.38 & 40.20 & 6.72 & 15.76 & 23.49 & 101.26 \\
\hline$d f$ & 2 & 2 & 2 & 2 & 2 & 2 \\
\hline$P$ & $<0.001$ & $<0.001$ & 0.035 & $<0.001$ & $<0.001$ & $<0.001$ \\
\hline \multicolumn{7}{|c|}{ F2 Generation } \\
\hline Diet & N1 $(n=496)$ & $\mathrm{N} 2(\mathrm{n}=335)$ & N3 $(n=285)$ & $\mathrm{N} 4(\mathrm{n}=263)$ & $\mathrm{N} 5(\mathrm{n}=244)$ & $\mathrm{N} 1-\mathrm{N} 5(\mathrm{n}=496)$ \\
\hline Beans & $77.31 \mathrm{a}$ & $86.24 \mathrm{a}$ & $92.02 \mathrm{a}$ & $93.06 \mathrm{a}$ & $94.41 \mathrm{a}$ & $53.90 \mathrm{a}$ \\
\hline Beans + pupae & $58.29 \mathrm{~b}$ & $83.62 \mathrm{a}$ & $92.78 \mathrm{a}$ & $92.22 \mathrm{a}$ & $92.77 \mathrm{a}$ & $38.69 \mathrm{~b}$ \\
\hline Artificial diet & $6.67 \mathrm{c}$ & $0.00 \mathrm{~b}$ & & & & $0.00 \mathrm{c}$ \\
\hline$\chi^{2}$ & 45.38 & 6.13 & 0.05 & 0.06 & 0.25 & 24.12 \\
\hline$d f$ & 2 & 2 & 1 & 1 & 1 & 2 \\
\hline$P$ & $<0.001$ & 0.050 & 0.082 & 0.803 & 0.614 & $<0.001$ \\
\hline
\end{tabular}




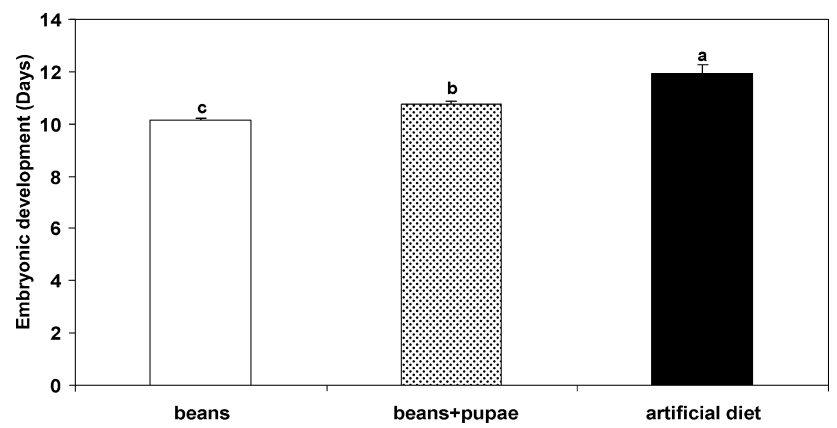

Fig. 1. Duration (Days; Mean \pm SE) of the embryonic development of F2 L. rugulipennis generation reared on different diets $\left(25 \pm 1{ }^{\circ} \mathrm{C}, 50-60 \%\right.$ r.h., 14L : 10D). Columns with the same letter are not significantly different $(\mathrm{F}=24.085$; d.f. $=2$, 493; P < 0.001; 1-way ANOVA).

duration of post-embryonic development; adult longevity; durations of the pre-oviposition, oviposition and post-oviposition periods; and number of eggs/female. Additionally, the following morphological parameters were also recorded, of both males and females: weight, using a high precision balance; width of cephalic capsule, length of one fore tibia and one hemelytron per bug, using a micrometric optic device (Leitz Wetzlar Germany $16 \times$ ) fitted to a stereo microscope.

The stage specific and total survival of F1 and F2 were analysed using the Karl Pearson $\chi^{2}$ test and, for the internal comparisons, the Goodman's post hoc procedure (Marascuilo \& Serlin, 1988) was applied. The total duration and stage dependent duration of post-embryonic development of F1 and F2, the adult longevity in both generations and the morphological parameters were submitted to 2-way ANOVA. The duration of embryonic development of the F2 generation was analyzed with 1-way ANOVA. All internal comparisons were submitted to unequal $\mathrm{N}$ HSD Tukey test (Statistica 6.0, Statsoft Inc., 2001). Data were tested for normality (Shapiro-Wilks W-test) and heteroscedasticity (Bartlett test) and, when necessary, were appropriately transformed (Statistica 6.0, Statsoft Inc., 2001; Zar, 1999).

Data concerning survival of the F1 and F2 L. rugulipennis generations were analysed by means of the cumulative proportion surviving analysis (Kaplan-Meier) (Kaplan \& Meier, 1958; Statistica 6.0, Statsoft Inc., 2001).

\section{RESULTS}

The stage-specific survival of the N1, N2, N4 and N5 instars of the first generation (F1) was significantly higher for nymphs reared on beans and beans + pupae, compared to those kept on the artificial diet, although in N3 instar the differences do not emerge in the internal

TABLE 2. Effects of diet (beans, beans + pupae, artificial diet; F2 nymphs did not survive on the artificial diet), sex and their interaction on the total duration of post-embryonic development of $\mathrm{F} 1$ and $\mathrm{F} 2 \mathrm{~L}$. rugulipennis generations $\left(25 \pm 1{ }^{\circ} \mathrm{C}, 50-60 \%\right.$ r.h., 14L : 10D) (2-way ANOVA) (see also Fig. 2).

\begin{tabular}{lcccccc}
\hline & \multicolumn{3}{c}{ F1 $(\mathrm{n}=215)$} & \multicolumn{3}{c}{ F2 $(\mathrm{n}=230)$} \\
\hline effect & $d f$ & $F$ & $P$ & $d f$ & $F$ & $P$ \\
\hline diet & 2 & 6.300 & 0.002 & 1 & 0.100 & 0.790 \\
sex & 1 & 6.400 & 0.012 & 1 & 2.200 & 0.135 \\
diet $\times$ sex & 2 & 3.120 & 0.046 & 1 & 0.900 & 0.339 \\
error & 209 & & & 226 & &
\end{tabular}

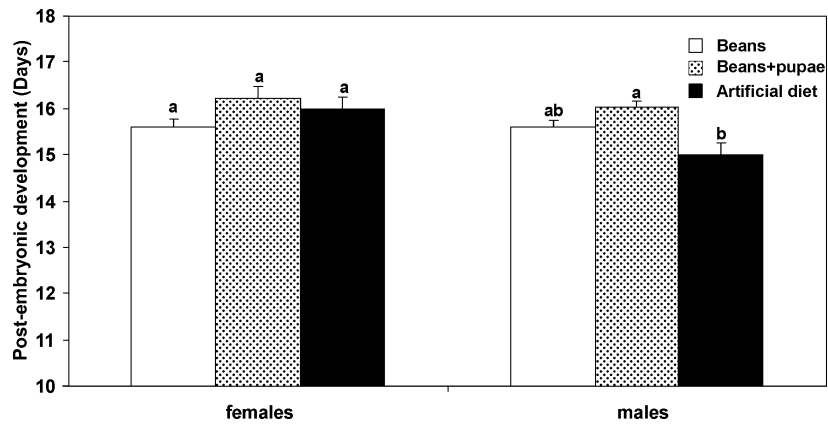

Fig. 2. Duration (Days; Mean $\pm \mathrm{SE}$ ) of the post-embryonic development of $\mathrm{F} 1$ L. rugulipennis males and females, reared on different diets $\left(25 \pm 1{ }^{\circ} \mathrm{C}, 50-60 \%\right.$ r.h., 14L : 10D). Columns of the same group with the same letter are not significantly different ( $\mathrm{P}>0.05$, Unequal N HSD Tukey test) (see also Table 2).

comparisons (Table 1). Consequently, total nymphal survival (N1-N5) was higher for individuals maintained on the beans and beans + pupae diets than on the artificial diet (Table 1).

Larger differences were recorded in the second generation (F2) (Table 1). For the N1 instar, there were significant differences among the three diets, with Lygus on beans surviving better than those reared on beans + pupae, or artificial diet (Table 1). Moreover, the survival of the N2 instar kept on the artificial diet was $0.0 \%$,

TABLE 3. Effects of diet (beans, beans + pupae, artificial diet; F2 nymphs did not survive on the artificial diet), sex and their interaction on the stage dependent duration of post-embryonic development of F1 and F2 L. rugulipennis generations (25 \pm $1{ }^{\circ} \mathrm{C}, 50-60 \%$ r.h., 14L : 10D) (2-way ANOVA) (see also Fig. $3)$.

\begin{tabular}{|c|c|c|c|c|c|c|c|}
\hline & & \multicolumn{3}{|c|}{ F1 $(n=215)$} & \multicolumn{3}{|c|}{$\mathrm{F} 2(\mathrm{n}=230)$} \\
\hline & effect & $d f$ & $F$ & $P$ & $d f$ & $F$ & $P$ \\
\hline \multirow[t]{4}{*}{ N1 } & diet & 2 & 0.428 & 0.652 & 1 & 0.058 & 0.809 \\
\hline & sex & 1 & 0.315 & 0.575 & 1 & 0.177 & 0.674 \\
\hline & diet $\times \operatorname{sex}$ & 2 & 0.074 & 0.928 & 1 & 0.001 & 0.969 \\
\hline & error & 209 & & & 226 & & \\
\hline \multirow[t]{4}{*}{$\mathrm{N} 2$} & diet & 2 & 0.320 & 0.726 & 1 & 3.860 & $<0.050$ \\
\hline & sex & 1 & 0.050 & 0.830 & 1 & 0.060 & 0.801 \\
\hline & $\operatorname{diet} \times \operatorname{sex}$ & 2 & 2.740 & 0.067 & 1 & 0.050 & 0.830 \\
\hline & error & 209 & & & 226 & & \\
\hline \multirow[t]{4}{*}{ N3 } & diet & 2 & 1.900 & 0.152 & 1 & 0.009 & 0.923 \\
\hline & sex & 1 & 3.270 & 0.072 & 1 & 0.451 & 0.502 \\
\hline & $\operatorname{diet} \times \operatorname{sex}$ & 2 & 0.750 & 0.472 & 1 & 1.496 & 0.222 \\
\hline & error & 209 & & & 226 & & \\
\hline \multirow[t]{4}{*}{ N4 } & diet & 2 & 0.130 & 0.880 & 1 & 0.012 & 0.912 \\
\hline & $\operatorname{sex}$ & 1 & 0.190 & 0.665 & 1 & 0.467 & 0.495 \\
\hline & $\operatorname{diet} \times \operatorname{sex}$ & 2 & 0.190 & 0.828 & 1 & 1.248 & 0.265 \\
\hline & error & 209 & & & 226 & & \\
\hline \multirow[t]{4}{*}{ N5 } & diet & 2 & 1.352 & 0.261 & 1 & 1.510 & 0.220 \\
\hline & sex & 1 & 0.336 & 0.562 & 1 & 1.499 & 0.222 \\
\hline & $\operatorname{diet} \times \operatorname{sex}$ & 2 & 0.924 & 0.398 & 1 & 1.477 & 0.225 \\
\hline & error & 209 & & & 226 & & \\
\hline
\end{tabular}




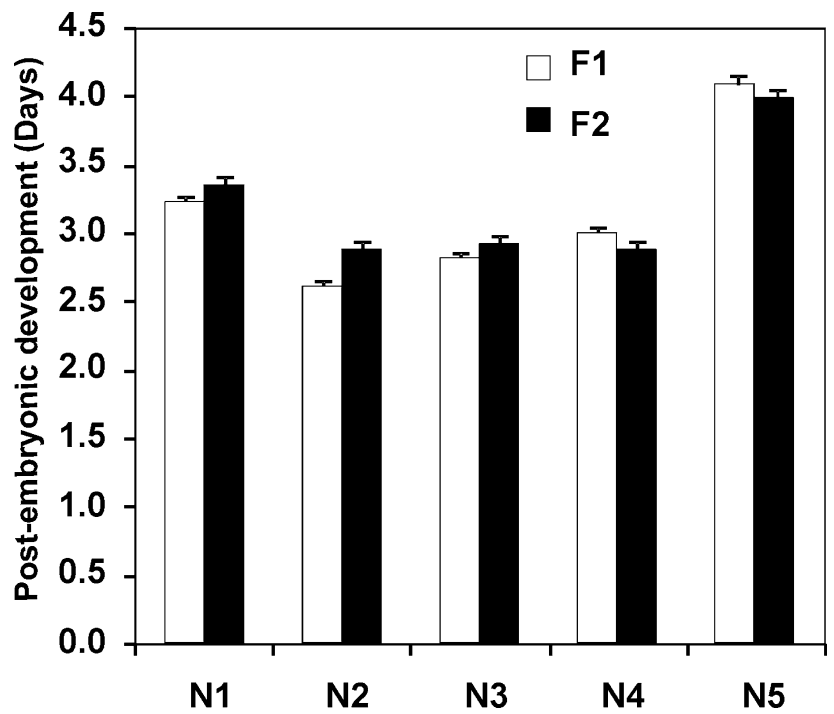

Fig. 3. Stage dependent (N1-N5) duration (Days; Mean \pm SE) of $\mathrm{F} 1$ and $\mathrm{F} 2$ L. rugulipennis generations, pooled data for the different diets and sexes $\left(25 \pm 1{ }^{\circ} \mathrm{C}, 50-60 \%\right.$ r.h., $\left.14 \mathrm{~L}: 10 \mathrm{D}\right)$ (see also Table 3).

resulting in the extinction of the F2 generation reared on this diet (Table 1). Total nymphal survival (N1-N5) was significantly different among the three diets, highest on beans, followed by beans + pupae and lowest on the artificial diet (Table 1), on which as already stated, no individuals survived.

The duration of embryonic development was evaluated only for the F2 generation, because it could have been influenced by the type of diet. Differences among diets were significant, with the shortest embryonic development recorded for the L. rugulipennis eggs produced by females reared and fed on beans, followed by beans + pupae and longest for those on artificial diet (Fig. 1).

The total duration of the post-embryonic development was evaluated both for the F1 and the F2 generations. In F1 the effects of diet, sex and their interaction were all significant (Table 2). Specifically, while the total devel-
TABLE 4. Effects of diet (beans, beans + pupae, artificial diet; F2 nymphs did not survive on the artificial diet), sex and their interaction on adult longevity of F1 and F2 L. rugulipennis generations $\left(25 \pm 1{ }^{\circ} \mathrm{C}, 50-60 \%\right.$ r.h., 14L : 10D) (2-way ANOVA) (see also Figs 4 and 5).

\begin{tabular}{lcccccc}
\hline & \multicolumn{3}{c}{ F1 $(\mathrm{n}=203)$} & \multicolumn{3}{c}{ F2 $(\mathrm{n}=205)$} \\
\hline effect & $d f$ & $F$ & $P$ & $d f$ & $F$ & $P$ \\
\hline diet & 2 & 12.145 & $<0.001$ & 1 & 9.166 & 0.003 \\
sex & 1 & 1.004 & 0.318 & 1 & 11.890 & $<0.001$ \\
diet $\times$ sex & 2 & 0.945 & 0.390 & 1 & 0.216 & 0.642 \\
error & 197 & & & 201 & & \\
\hline
\end{tabular}

opmental time of females did not differ significantly among diet types, the males took longer to develop on beans + pupae than on the artificial diet, and an intermediate time to develop on beans (Fig. 2). In F2 none of the effects were significant $(16.03 \pm 0.09$; mean $\pm \mathrm{SE})$ (Table 2).

The duration of individual nymphal stages was also evaluated for the F1 and F2 generations. The effects of diet, sex and their interaction during the different nymphal instars were not significant, except for a diet effect on the N2 instar of F2 (beans: $2.77 \pm 0.07$; beans + pupae: $3.08 \pm 0.14$; mean \pm SE) (Table 3 and Fig. 3).

In the case of adult longevity, diet only significantly affected the F1, whereas both diet and sex effects were significant in F2, but not their interaction (Table 4).

$\mathrm{F} 1$ adults lived longer on beans and beans + pupae than on artificial diet (Figs 4 and 5). F2 adults lived longer when maintained on beans compared to beans + pupae and females lived longer than males (Figs 4 and 5).

The duration of the pre-oviposition period of F1 and F2 females did not differ significantly among diets (Fig. 6). On the other hand the oviposition period in F1 was significantly longer when females were reared on beans and beans + pupae than on the artificial diet (Fig. 6), and in F2 it was significantly longer for those kept on beans than on beans + pupae (Fig. 6). Both in F1 and F2 there were
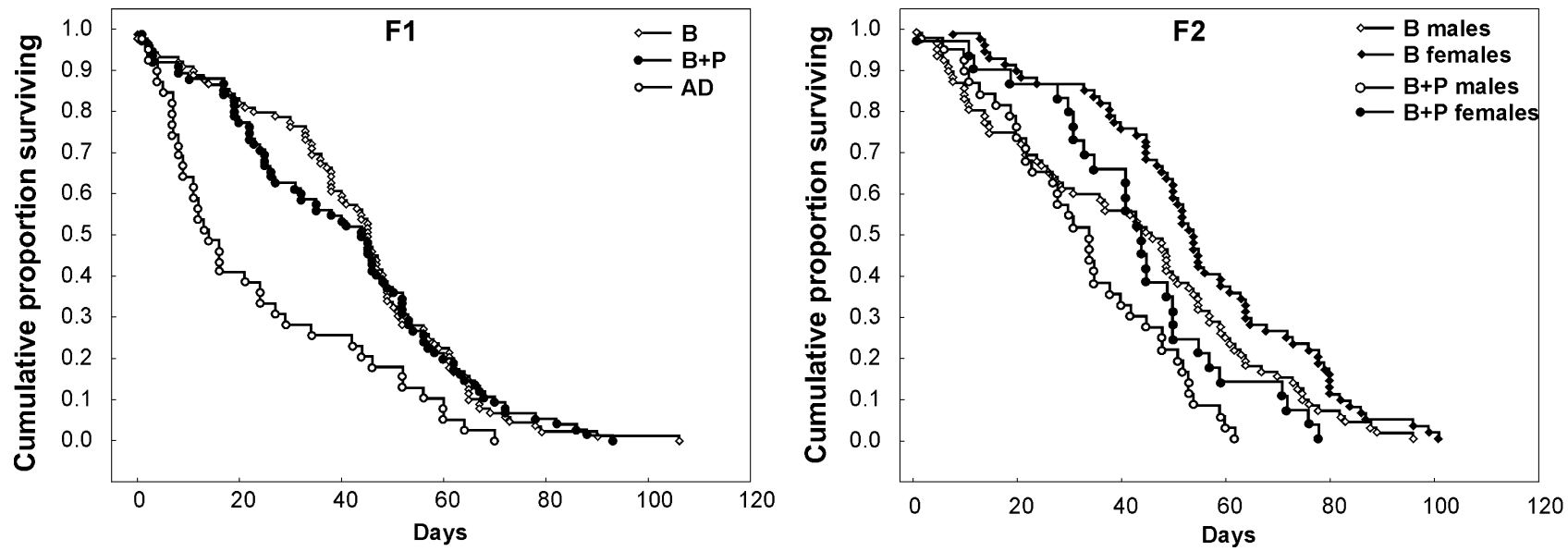

Fig. 4. Survival of F1 L. rugulipennis generation reared on beans (B), beans + pupae $(B+P)$ and artificial diet (AD), pooled data for both sexes $\left(\chi^{2}=20.25\right.$; d.f. $=2$; $\mathrm{P}<0.001$; Kaplan-Meier $)$ and $\mathrm{F} 2$ generation reared on beans and beans + pupae $\left(\chi^{2}=22.49\right.$; d.f. $=3 ; \mathrm{P}<0.001$; Kaplan-Meier $)\left(25 \pm 1{ }^{\circ} \mathrm{C}, 50-60 \%\right.$ r.h., $\left.14 \mathrm{~L}: 10 \mathrm{D}\right)$. 

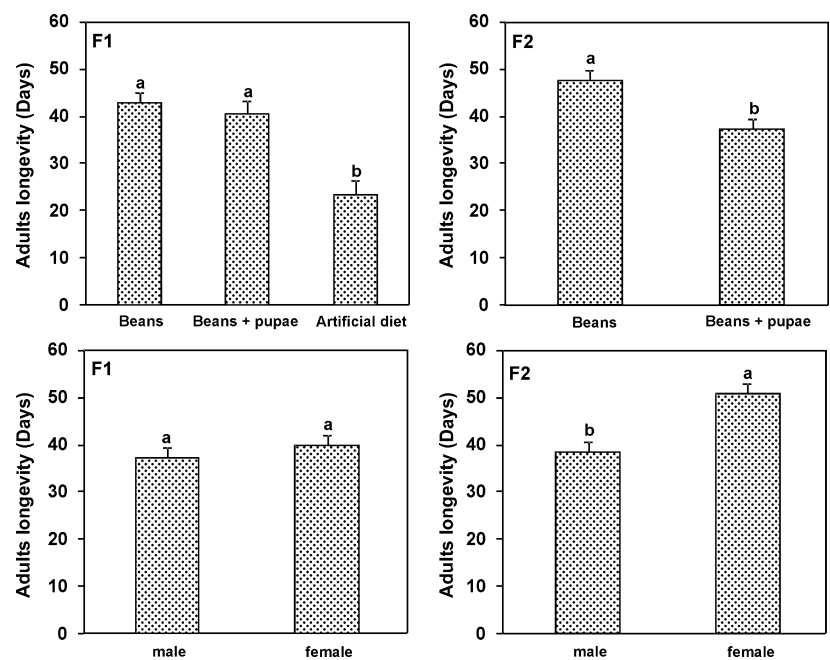

Fig. 5. Adult longevity of F1 and F2 L. rugulipennis reared on different diets (data for sexes pooled) and of different sexes (data for diets pooled) $\left(25 \pm 1{ }^{\circ} \mathrm{C}, 50-60 \%\right.$ r.h., 14L : 10D). Columns with the same letter are not significantly different $(\mathrm{P}>$ 0.05, Unequal N HSD Tukey test) (see also Table 4).

no significant differences in the duration of the postoviposition period among the diets (Fig. 6).

Female fecundity was also influenced by the diet. F1 females laid significantly more eggs when maintained on bean and bean + pupae compared with those on the artifi-
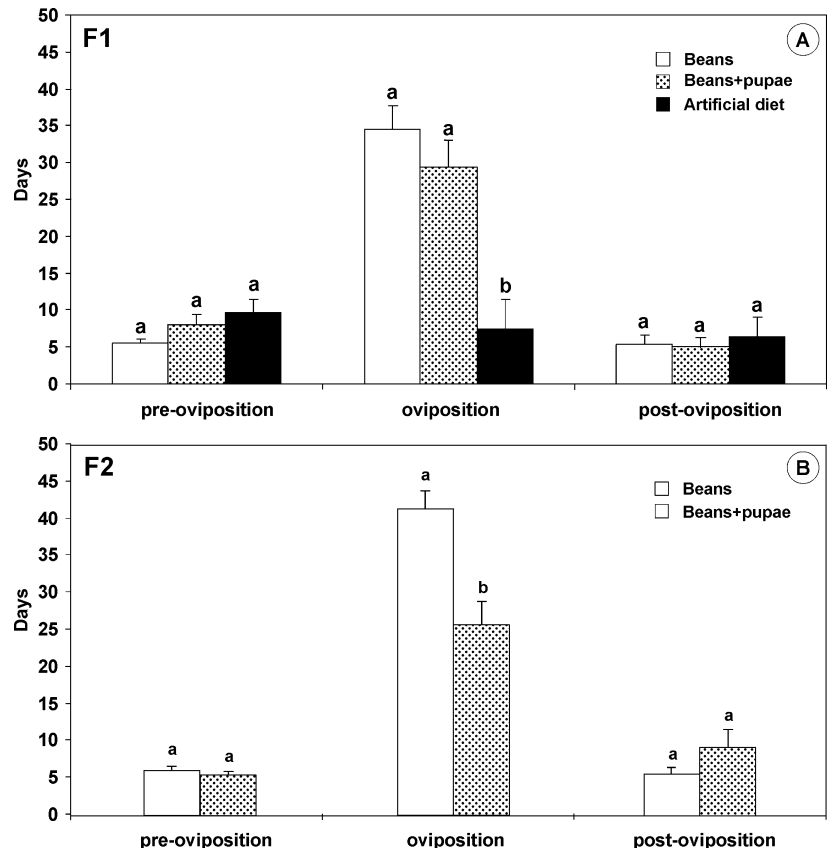

Fig. 6. Durations (Days; Mean $\pm \mathrm{SE}$ ) of the pre-oviposition $(\mathrm{F} 1: \mathrm{F}=3.644 ;$ d.f. $=2,68 ; \mathrm{P}=0.031 ; \mathrm{F} 2: \mathrm{F}=1.066$; d.f. $=1$, 94; $\mathrm{P}=0.305)$, oviposition ( $\mathrm{F} 1: \mathrm{F}=17.640$; d.f. $=2$, 79; $\mathrm{P}<$ $0.001 ; \mathrm{F} 2: \mathrm{F}=14.008$; d.f. $=1,98 ; \mathrm{P}<0.001)$ and postoviposition periods ( $\mathrm{F} 1: \mathrm{F}=0.141$; d.f. $=2,65 ; \mathrm{P}=0.868 ; \mathrm{F} 2$ : $\mathrm{F}$ $=0.859$; d.f. $=1,89 ; \mathrm{P}=0.357)$ of the $\mathrm{F} 1(\mathrm{~A})$ and $\mathrm{F} 2(\mathrm{~B})$ generations of L. rugulipennis females reared on different diets $(25$ $\pm 1{ }^{\circ} \mathrm{C}, 50-60 \%$ r.h., 14L : 10D). Columns of the same group with the same letter are not significantly different $(\mathrm{P}>0.05$, Unequal N HSD Tukey test).

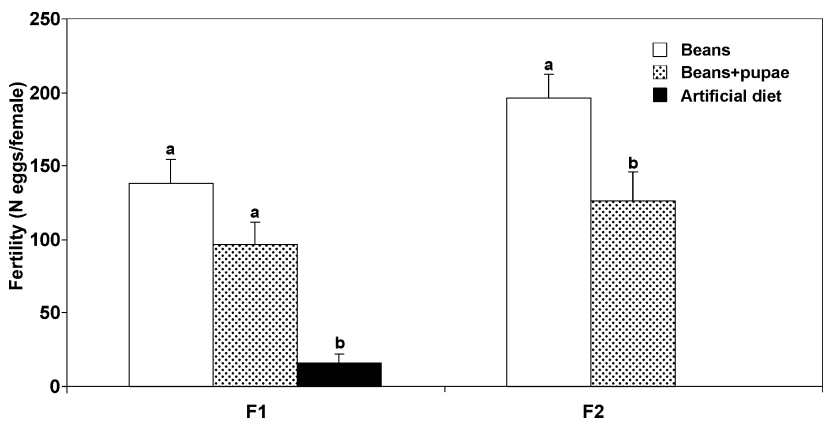

Fig. 7. Fecundity (Number of eggs laid/female; Mean \pm SE) of F1 ( $\mathrm{F}=18.928$; d.f. $=2,79 ; \mathrm{P}<0.001)$ and $\mathrm{F} 2(\mathrm{~F}=9.497$; d.f. $=1,98 ; \mathrm{P}=0.003)$ L. rugulipennis females $\left(25 \pm 1{ }^{\circ} \mathrm{C}\right.$, $50-60 \%$ r.h., 14L : 10D). Columns of the same group with the same letter are not significantly different $(\mathrm{P}>0.05$, Unequal $\mathrm{N}$ HSD Tukey test).

cial diet, and egg production in the F2 was higher for females on bean compared to bean + pupae (Fig. 7).

The diet did not influence the morphological parameters (i.e., weight, width of cephalic capsule, and tibia and hemelytron length) of males and females. However, sex of the bugs significantly affected the weight in the F1, in which females were heavier than males (female $=0.008 \mathrm{~g}$ \pm 0.0001 ; male $=0.007 \mathrm{~g} \pm 0.0001$. Mean $\pm \mathrm{SE}$ ), and the width of cephalic capsule in the F2, with males having smaller heads (female $=1128.37 \mu \mathrm{m} \pm 4.05$; male $=$ $1108.04 \mu \mathrm{m} \pm$ 3.5. Mean $\pm \mathrm{SE}$ ) (Table 5).

\section{DISCUSSION}

In our laboratory experiments, the artificial diet developed for rearing L. hesperus (Debolt, 1982; Patana, 1982; Debolt \& Patana, 1985; Cohen, 2000; Habibi et al., 2001; Zeng \& Cohen, 2001) was not as good as the vegetable

TABLE 5. Effects of diet, sex and their interaction on the morphological parameters of $\mathrm{F} 1$ and $\mathrm{F} 2$ L. rugulipennis adults $(25 \pm$ $1^{\circ} \mathrm{C}, 50-60 \%$ r.h., 14L : 10D) (2-way ANOVA).

\begin{tabular}{llcccccc}
\hline & & \multicolumn{3}{c}{ F1 $(\mathrm{n}=175-211)$} & \multicolumn{3}{c}{ F2 $(\mathrm{n}=189-228)$} \\
\hline Weight & effect & $d f$ & $F$ & $P$ & $d f$ & $F$ & $P$ \\
& diet & 2 & 0.421 & 0.657 & 1 & 0.513 & 0.474 \\
& sex & 1 & 24.492 & $<0.001$ & 1 & 0.435 & 0.510 \\
& diet $\times$ sex & 2 & 0.342 & 0.711 & 1 & 1.634 & 0.202 \\
& error & 205 & & & 224 & & \\
\hline Head & diet & 2 & 1.059 & 0.349 & 1 & 1.237 & 0.267 \\
width & sex & 1 & 1.846 & 0.176 & 1 & 13.083 & $<0.001$ \\
& diet $\times$ sex & 2 & 2.361 & 0.097 & 1 & 0.041 & 0.840 \\
& error & 174 & & & 188 & & \\
\hline Tibia & diet & 2 & 0.623 & 0.538 & 1 & 3.275 & 0.072 \\
length & sex & 1 & 1.264 & 0.263 & 1 & 0.012 & 0.912 \\
& diet $\times$ sex & 2 & 0.123 & 0.885 & 1 & 0.138 & 0.711 \\
& error & 169 & & & 189 & & \\
\hline Hem- & diet & 2 & 0.845 & 0.431 & 1 & 0.189 & 0.665 \\
elytron & sex & 1 & 0.001 & 0.981 & 1 & 2.813 & 0.095 \\
length & diet $\times$ sex & 2 & 0.993 & 0.373 & 1 & 0.136 & 0.713 \\
& error & 173 & & & 185 & & \\
\hline
\end{tabular}


diet for L. rugulipennis, as indicated by reduced survival and longevity in the F1 generation, and extinction in the F2. L. rugulipennis fecundity, evaluated as number of eggs laid, was also lower in females reared on the artificial diet compared to those reared on fresh green beans. This may be because of the diet or the lower suitability of the artificial oviposition substrate (agar-parafilm cylinders) compared to beans, as indicated by preliminary tests. In laboratory choice tests L. rugulipennis females preferred to oviposit into fresh green beans compared to artificial substrates, even when these were treated with bean extracts (data not shown), as suggested by Whitbey (1999) for L. hesperus.

Rearing on the artificial diet also appears to affect embryonic development, suggesting a poor yolk quality. However, other effects of the artificial oviposition substrate on embryonic development should be evaluated.

In our experiments it was difficult to separate the effects of the artificial diet and artificial oviposition substrate. It was not possible to combine a natural diet with an artificial oviposition substrate and vice-versa, because oviposition behaviour in Lygus species is always linked with stylet probing (Romani et al., 2005).

Lygus spp., as many mirid bugs and other Heteroptera, often show a partial zoophagy (Wagner \& Weber, 1964; Alomar \& Wiedenmann, 1996; Wheeler, 2001; Boyd et al., 2002; Boyd, 2003), which in several cases is confirmed by the enzyme profiles of the saliva. For example, there is protease in addition to pectinase and amylase in the saliva of $L$. hesperus, L. lineolaris and L. rugulipennis, suggesting that during extra-oral digestion they are capable of ingesting structural proteins from animals (Laurema et al., 1985; Agusti \& Cohen, 2000). A partial zoophagy was, in fact, also noticed in the case of L. rugulipennis fed on Aphis fabae and Tenebrio molitor pupae (personal observations). However, in our experiments this species developed better on a diet of fresh green beans than on a combined diet composed of green beans and $T$. molitor pupae. These results may suggest that the nutritional quality of these pupae is not suitable for L. rugulipennis, although they are commonly used as protein source in mass rearing of many heteropteran predators (Oliveira et al., 1999, 2004; Jusselino et al., 2001; Zanuncio et al., 2001). Therefore, future research should also consider alternative animal sources of protein.

Because the lack of positive results in the use of an artificial diet to rear L. rugulipennis, further efforts are needed to improve this diet and in particular to find a suitable oviposition substrate for the mass rearing of this species. In addition, a suitable oviposition substrate will allow the mass rearing of the specific egg parasitod, $A$. fuscipennis, for use as a biological control agent (Conti et al., 1994; Coutinot \& Hoelmer, 1999) in IPM programmes. In fact, maintaining this parasitoid on host eggs embedded in green beans is very difficult (personal observations) as the beans tend to deteriorate rapidly under standard rearing conditions.

ACKNOWLEDGEMENTS. We are grateful to M. Siena and G. Ioli for help with the data collection and A. Onofri for statistical support. This work was financially supported by MIUR - Programmi di Ricerca Scientifica di Rilevante Interesse Nazionale (PRIN) - "Direct and indirect defences in crop plants for a sustainable control of insect pests", no. 2004075974.

\section{REFERENCES}

Agusti N. \& Cohen A.C. 2000: Lygus hesperus and L. lineolaris (Hemiptera: Miridae), phytophages, zoophages, or omnivores: evidence of feeding adaptations suggested by the salivary and midgut digestive enzymes. J. Entomol. Sci. 35: 176-186.

Alomar O. \& Wiedenmann R.N. 1996: Zoophytophagous Heteroptera: Implications for Life History and Integrated Pest Management. The Entomological Society of America, Thomas Say Publications in Entomology, Lanham, Maryland, $202 \mathrm{pp}$.

Beards G.W. \& Leigh T.F. 1960: A laboratory rearing method for Lygus hesperus Knight. J. Econ. Entomol. 53: 327-328.

Bilewicz-PawińsKa T. 1983: Anaphes fuscipennis Haliday (Hymenoptera, Mymaridae), an egg parasite of Lygus rugulipennis Poppius (Heteroptera, Miridae) previously unrecorded in Poland. Pol. Pis. Entomol. 53: 417-423.

Boyd D.W. JR. 2003: Digestive enzymes and stylet morphology of Deraeocoris nigritulus (Uhler) (Hemiptera: Miridae) reflect adaptations for predatory habits. Ann. Entomol. Soc. Am. 96: 667-671.

Boyd D.W. JR., Cohen A.C. \& Alverson D.R. 2002: Digestive enzymes and stylet morphology of Deraeocoris nebulosus (Hemiptera: Miridae), a predacious plant bug. Ann. Entomol. Soc. Am. 95: 395-401.

Cohen A.C. 2000: A review of feeding studies of Lygus spp. with emphasis on artificial diets. Southw. Entomol. (Suppl.) 23: 111-119.

Colazza S. \& Contr E. 2000: Animali dannosi alle piante industriali. In Baccetti B., Barbagallo S., Süss L. \& Tremblay E. (eds): Manuale di Zoologia Agraria. Antonio Delfino Editore, Roma, pp. 381-402.

Conti E. \& Bin F. 2001: Native Lygus spp. (Heteroptera: Miridae) damaging introduced Hibiscus cannabinus in Italy. $J$. Econ. Entomol. 94: 648-657.

Conti E., Ayano EjIgu B. \& Bin F. 1994: Distribuzione e parassitizzazione delle uova di Lygus spp. sul girasole in Italia centrale (Heteroptera: Miridae; Hymenoptera: Mymaridae). Atti XVII Congr. Naz. Ital. Entomol., Udine 13-18 giugno 1994. pp. 523-526.

Coutinot D. \& Hoelmer K. 1999: Parasitoids of Lygus spp. in Europe and their potential for biological control of Lygus spp. in North America. Proceedings of the Fifth International Conference on Pests in Agriculture, Montpellier, France, 7-9 December 1999. Part 3. Association of National Protection of Plants, Paris, pp. 641-648.

Debolt J.W. 1982: Meridic diet for rearing successive generations of Lygus hesperus. Ann. Entomol. Soc. Am. 75: $119-122$.

Debolt J.W. \& Patana R. 1985: Lygus hesperus. In Singh P. \& Moore R.F. (eds): Handbook of Insect Rearing. Vol. 1. Elsevier, New York, 329 pp.

D’Ovidio R., Raiola A., Capodicasa C., Devoto A., Pontiggia D., Roberti S., Galletti R., Conti E., O’Sullivan D \& DE Lorenzo G. 2004: Characterisation of the complex locus of Phaseolus vulgaris encoding polygalacturonase-inhibiting proteins (PGIPs) reveals sub-functionalization for defence against fungi and insects. Plant Physiol. 135: 2424-2435.

Frati F., Galletti R., De Lorenzo G., Salerno G. \& Conti E. 2006: Activity of endo-polygalacturonase in mirid bugs (Het- 
eroptera: Miridae) and their inhibition by plant cell wall proteins (PGIPs). Eur. J. Entomol. 103: 515-522.

Habibi J., Backus E.A., Coudron T.A. \& Brandt S.L. 2001: Effect of different host substrates on hemipteran salivary protein profiles. Entomol. Exp. Appl. 98: 369-375.

HiLl D.S. 1987: Agricultural Insect Pests of Temperate Regions and Their Control. Cambridge University Press, Cambridge, $\mathrm{UK}, 659 \mathrm{pp}$.

Holopainen J.K. 1989: Host plant preference of the tarnished plant bug Lygus rugulipennis Popp. (Heteroptera, Miridae). $J$. Appl. Entomol. 107: 78-82.

Holopainen J.K. \& VARIS A.L. 1991: Host plants of the European tarnished plant bug Lygus rugulipennis Popp. (Heteroptera: Miridae). J. Appl. Entomol. 111: 484-498.

Jusselino Filho P., Zanuncio J.C., Guedes R.N.C. \& Fragoso D.B. 2001: Development and reproduction of the predator Brontocoris tabidus (Heteroptera: Pentatomidae) fed with larvae of Tenebrio molitor (Col.: Tenebrionidae). Rev. Colomb. Entomol. 27: 45-48.

Kaplan E.L. \& Meier P. 1958: Nonparametric estimation from incomplete observations. J. Am. Stat. Assoc. 53: 457-481.

Laurema S., Varis A.L. \& MietTinen H. 1985: Studies on enzymes in the salivary glands of Lygus rugulipennis (Hemiptera: Miridae). Insect Biochem. 15: 211-224.

Marascuilo L.A. \& SERLIN R.C. 1988: Statistical Methods for the Social and Behavioral Sciences. W.H. Freeman, New York, $804 \mathrm{pp}$.

Oliveira H.N., Zanuncio J.C., Sossai M.F. \& Pratissoli D. 1999: Body weight increment of Podisus distinctus (Stål) (Heteroptera: Pentatomidae), fed on Tenebrio molitor L. (Coleoptera: Tenebrionidae) or Musca domestica L. (Diptera: Muscidae). Brenesia 51: 77-83.

Oliveira H.N. de, Pratissoli D., Pedruzzi E.P. \& Espindula M.C. 2004: Development of the predator Podisus nigrispinus fed on Spodoptera frugiperda and Tenebrio molitor. Pesq. Agropec. Bras. 39: 947-951.

Patana R. 1982: Disposable diet packet for feeding and oviposition of Lygus hesperus (Hemiptera: Miridae). J. Econ. Entomol. 4: 668-669.

Patana R. \& Debolt J.W. 1985: Rearing Lygus hesperus in the laboratory. USDA ARS Bull. 45: 1-9.
Romani R., Salerno G., Frati F., Conti E., Isidoro N. \& Bin F. 2005: Oviposition behaviour in Lygus rugulipennis (Heteroptera: Miridae): a morphofunctional study. Entomol. Exp. Appl. 115: $17-25$.

Schwartz M.D. \& Foottit R.G. 1998: Revision of the Nearctic Species of the Genus Lygus Hahn, With a Review of the Palaearctic Species (Heteroptera: Miridae). Memoirs on Entomology, International Vol. 10. Associated Publishers, Gainesville, FL, viii + 428 pp.

StatSoft Inc. 2001: Statistica (data analysis software system), version 6. StatSoft Italia S.r.l., Vigonza (PD), Italy.

Strong F.E. 1970: Physiology of injury caused by Lygus hesperus. J. Econ. Entomol. 63: 808-814.

Tavella L., Alma A. \& Arzone A. 1997: Lygus rugulipennis Poppius, a minor pest in the peach orchards of northwestern Italy. Integrated plant protection in stone fruit. Proceedings of the Meeting at Zaragozza, Spain, 24-26 September 1996. Bull. OILB-SROP 20: $1-5$.

VARIS A.L. 1972: The biology of Lygus rugulipennis Popp. (Het. Miridae) and the damage caused by this species to sugar beet. Ann. Entomol. Fenn. 1: 1-56.

Wagner E.H. \& Weber H. 1964: Faune de France. Vol. 67. Hétéroptères Miridae. Fédération Française des Sociétés de Sciences Naturelles, Paris, 591 pp.

WheELer A.G. JR 2001: Biology of the Plant Bugs. Cornell University Press, Ithaca, $506 \mathrm{pp}$.

WhitBey R.M. 1999: Green bean extract-induced oviposition site preference in laboratory reared western tarnished plant bug (Heteroptera: Miridae). Environ. Entomol. 28: 201-204.

Zanuncio J.C., Molina-Rugama A.J., Serrão J.E. \& Pratissoli D. 2001: Nymphal development and reproduction of Podisus nigrispinus (Heteroptera: Pentatomidae) fed with combinations of Tenebrio molitor (Coleoptera: Tenebrionidae) pupae and Musca domestica (Diptera: Muscidae) larvae. Biocontr. Sci. Techn. 11: 331-337.

ZAR J.H. 1999: Biostatistical Analysis. Prentice Hall, NJ, 663 pp.

ZENG F. \& COHEN A.C. 2001: Induction of elastase in a zoophytophagous heteropteran, Lygus hesperus (Hemiptera: Miridae). Ann. Entomol. Soc. Am. 94: 146-151.

Received March 28, 2006; revised and accepted March 14, 2007 